\title{
Greves, sindicatos e repressão policial no Rio de Janeiro (1954-1964)
}

Marcelo Badaró Mattos ${ }^{1}$

UFF

RESUMO

Este artigo apresenta parte dos resultados de uma pesquisa sobre as greves e a repressão aos sindicatos no Rio de Janeiro entre 1954 e 1964. Seu objetivo central é rediscutir a relação entre Estado, empresários e trabalhadores organizados no período em questão a partir da dimensão de conflito explicitada nos momentos de greve. Pretendeu-se também apresentar dados mais completos que os anteriormente disponíveis sobre o total e as características das greves, bem como explorar o potencial da documentação policial, aberta à consulta nos últimos anos.

Palavras-chave: Sindicalismo; greves; polícia política.

\section{ABSTRACT}

This article presents some conclusions on strikes and police repression to trade unions in Rio de Janeiro. The central question is the relation between State, capitalists and organized workers in that moment, with special attention to the conflict dimension expressed by strikes. The article tries to show more complete data about strike numbers and characteristics, as well as to explore the recently opened police documents.

Keywords: Trade-unionism; strikes; political police.

O movimento sindical costuma ser apontado como um dos protagonistas do período imediatamente anterior ao golpe de 1964, mas as dimensões efetivas de seu poder de mobilização para ação coletiva organizada — das quais as greves são um bom indicador — ainda motivam polêmicas. Porém, se muita atenção foi dada aos discursos e políticas estatais de aproximação com os trabalhadores — ora definidos pela categoria populismo, ora abarcados na rubrica do trabalhismo - ainda parece insuficiente o acúmulo de discussões sobre a ação estatal repressiva que incidia sobre as organizações sindicais, da qual a polícia política é um instrumento dos mais importantes.

Para a pesquisa que embasou este artigo, lançamos mão de dois grandes conjuntos de fontes: de um lado, os registros jornalísticos das greves na im- 
prensa (jornais diários e imprensa partidária ou sindical); de outro, os dossiês policiais sobre greves, sindicatos e temas correlatos armazenados nos arquivos das polícias políticas recolhidos ao Arquivo Público do Estado do Rio de Janeiro.

\section{GREVES}

Ao iniciar a discussão sobre greves no Brasil das décadas de 1950 e 1960, é preciso constatar que as análises correntes assentam-se sobre uma dificuldade fundamental: há uma carência de levantamentos quantitativos confiáveis sobre o tema. Não há estatísticas oficiais de greves, até pelo menos a década de 1980, e os órgãos de assessoria sindical que se encarregaram de registrar os movimentos também iniciaram seus levantamentos no fim dos anos 70 . Buscamos partir de uma base de dados a mais ampla possível, sobre um espaço delimitado (a cidade do Rio de Janeiro), de forma a tentar minorar essa carência de informações quantificáveis confiáveis. Assim, foi-nos possível confrontar os números de greves apresentados em trabalhos anteriores. A título de comparação, é possível tomar em conta os dados oferecidos por alguns levantamentos apresentados pela literatura especializada. Leôncio Rodrigues, por exemplo, baseando-se em estudo de Régis Andrade, mencionou oitenta greves no Rio de Janeiro, no período 1958 a 1963. Em estudo muito mais detalhado, Salvador Sandoval localizou 168 greves no Rio entre 1945 e $1968 .^{2}$

A primeira constatação a que podemos chegar a partir dos dados levantados em nossa pesquisa, que reconhecemos devem ser inferiores à efetiva quantidade de greves no período, é a de que os levantamentos disponíveis apresentavam números muito subestimados, ainda que em nossa pesquisa centremos atenção apenas no caso da cidade do Rio de Janeiro — Distrito Federal na maior parte do período e depois Estado da Guanabara - não computando dados do antigo estado do Rio, a não ser quando os sindicatos e categorias extrapolavam os limites da capital (como os ferroviários, por exemplo). Afinal, localizamos um total de 480 greves entre 1945 e 1964, número três vezes maior que o levantado por Sandoval. Apenas no período 19581963, em que o estudo de Rodrigues citado encontrou oitenta greves, localizamos 307 paredes, número quase quatro vezes superior. Para o período 1954-1964, apresentamos o total anual de greves na Tabela 1. 
Tabela 1

Greves na Cidade do Rio de Janeiro 1954-1964

\begin{tabular}{lc}
\hline Ano & Número de greves \\
\hline 1954 & 14 \\
\hline 1955 & 18 \\
\hline 1956 & 22 \\
\hline 1957 & 16 \\
\hline 1958 & 7 \\
\hline 1959 & 32 \\
\hline 1960 & 35 \\
\hline 1961 & 56 \\
\hline 1962 & 61 \\
\hline 1963 & 77 \\
\hline 1964 & 38 \\
\hline Total: & 376 \\
\hline
\end{tabular}

Fontes (desta e das demais tabelas): Imprensa diária (Biblioteca Nacional) e dossiês policiais (Arquivo Público do Estado do Rio de Janeiro).

Quanto aos ciclos grevistas da fase mais ampla compreendida entre as ditaduras do Estado Novo e Militar, há claramente um primeiro momento de estouro das paralisações, em 1946, ao qual se seguem dois anos de quase completa inexistência de movimentos grevistas. Nos anos seguintes, até meados da década de 1950, mantém-se, com oscilações, um patamar semelhante e uma continuidade de atividades grevistas, com cinco greves no ano de mais baixa atividade (1951) e 23 paredes no ano de maior agitação (1956). É justamente no período da segunda metade dos anos 50 e primeiros anos da década de 1960 que a curva de movimentos grevistas toma um rumo ascendente significativo, com saltos sucessivos no número de paralisações, que configuraram uma das fases mais dinâmicas do movimento operário brasileiro. ${ }^{3}$

As informações sobre o número de greves ganhariam em densidade se com elas pudéssemos combinar séries completas de números de trabalhado- 
res parados e de dias de duração das paralisações (de forma a calcularmos o número de jornadas perdidas). Séries desse tipo permitiriam a aplicação de métodos de quantificação da dimensão do impacto das greves, como os desenvolvidos por Tilly e Shorter. ${ }^{4}$ Nossas fontes são pouco precisas quanto a esse tipo de dados. Utilizando o exemplo do ano de 1962, obtivemos registros de número de trabalhadores parados em 18,03\% do total de 61 greves e de dias parados em 67,21\% delas. Nestes casos, encontramos às médias de 5.959,09 grevistas e 10,32 dias parados. Com base nessa amostra, pode-se contatar, por exemplo, que muitas eram as greves que duravam até 24 horas (computadas como um dia), cujo total foi de 16. Algumas greves ultrapassavam os dez dias de paralisação, mais precisamente nove nesta nossa amostra. Pela fração da amostra em que há registros de número de trabalhadores parados, deduz-se que as greves envolveram entre 350 e 18 mil trabalhadores, não incluindo no cálculo os participantes das greves gerais, para as quais não dispomos de dados locais seguros.

Adentrando os aspectos qualitativos dos movimentos, a pesquisa mais apurada das greves também permite relativizações e refutações de diversas teses clássicas. É o caso das caracterizações do "sindicalismo populista”, expressão compartilhada por diversos autores que, apesar de partirem de modelos diferentes de análise, concordam na apreciação negativa do movimento sindical no período, realçando suas limitações. Numa síntese esquemática, o "sindicalismo populista" seria caracterizado por: a) inconsistência organizatória (organizações de cúpula - oficiais ou paralelas — seriam privilegiadas em relação às Organizações por Local de Trabalho); b) falta de questionamento à estrutura sindical, até mesmo por parte da direção comunista; c) falta de sintonia entre lideranças (com discurso e reivindicações nacionais e politizadas) e suas bases (mobilizadas apenas por questões salariais); d) poder de mobilização concentrado nos trabalhadores do Estado e escasso entre os empregados do setor privado, em especial nos setores de ponta da grande indústria; e) privilégio ao Estado como interlocutor principal dos sindicatos, subordinação aos políticos populistas e secundarização do conflito capital e trabalho. ${ }^{5}$

A uma tal caracterização corresponderia uma tipificação das greves no período em questão como: a) de natureza salarial, mais que motivadas por questões políticas ou sindicais; b) de categoria, mais que de empresas; c) cada vez mais concentradas no setor público, em detrimento do privado; d) garantidas por piquetes, forçando a adesão "de fora para dentro das empresas", e não por organizações internas aos locais de trabalho; e) inexistência de repressão violenta às greves dos primeiros anos da década de $1960 .^{6}$ 
Resgatamos os dados da pesquisa para a análise, por partes. Começamos pelos dados sobre a abrangência das greves. No período pesquisado, as greves por empresa praticamente equivalem em quantidade às greves por categorias, conforme se pode observar na Tabela 2.2, que apresenta o total, para o período 1954-1964, de 180 greves por empresa e 190 greves por categorias, além de três greves envolvendo mais de uma categoria e três greves gerais.

Tabela 2

Tipos de Greves - abrangência

\begin{tabular}{lccccc}
\hline Anos & Por Empresa & Por Categoria & Intercategorias & Geral & Total \\
\hline 1954 & 8 & 6 & - & - & 14 \\
\hline 1955 & 10 & 8 & - & - & 18 \\
\hline 1956 & 9 & 13 & - & - & 22 \\
\hline 1957 & 7 & 9 & - & - & 16 \\
\hline 1958 & 2 & 5 & - & - & 7 \\
\hline 1959 & 15 & 17 & - & - & 32 \\
\hline 1960 & 19 & 15 & 1 & - & 35 \\
\hline 1961 & 21 & 35 & - & - & 56 \\
\hline 1962 & 32 & 26 & 1 & 2 & 61 \\
\hline 1963 & 36 & 40 & 1 & - & 77 \\
\hline 1964 & 21 & 16 & - & 1 & 38 \\
\hline Totais & 180 & 190 & 3 & 3 & 376 \\
\hline
\end{tabular}

São números que põem em questão tanto a idéia de que havia um predomínio absoluto das greves por categoria, quanto a conclusão dela derivada de que as greves se faziam "de fora para dentro da empresa", a partir da ação de piquetes, por decisão de direções sindicais distantes de suas bases. Afinal, para fazer a greve nas empresas, era necessário algum nível de organização no local de trabalho (OLT), elemento que foi localizado por diversos estudos recentes, em especial quando examinando a conjuntura da redemocratização de 1945-1946, o que tem levado a várias relativizações da tese de que a estrutura sindical acabava por impedir a mobilização autônoma dos trabalhado- 
res. $^{7}$ A presença das OLTs atravessa todo o período, em categorias industriais, como os metalúrgicos e os têxteis, em categorias manufatureiras, como os marceneiros, e em categorias do setor de serviços, como os bancários.

Trabalhando com exemplos, podemos citar, nos anos 60, uma greve dos trabalhadores da fábrica de móveis L. Martins, ocorrida em janeiro de 1961. A greve, que durou dois dias, foi de ocupação (os trabalhadores ingressaram na empresa, mas não ligaram as máquinas) e à sua frente estava o Conselho Sindical da fábrica. ${ }^{8}$ A presença das OLTs era importante não apenas nas greves por empresas, mas também em muitas greves por categoria. Assim entendemos, por exemplo, o sucesso das greves bancárias dos primeiros anos da década de 1960, quando a categoria paralisava nacionalmente suas atividades, mas a construção da greve dependia das Comissões Sindicais, presentes em praticamente todas as agências, dos comandos de greve e comissões de piquetes, que envolviam, no conjunto, uma grande parte da categoria. Uma categoria, aliás, cujo percentual de filiação sindical no Rio de Janeiro chegava a 75\% naqueles anos. ${ }^{9}$

Ao estimularem (ou atuarem conjuntamente com) as OLTs, os sindicatos iam além da estrutura oficial. Nos momentos em que essas organizações agiam de forma independente da estrutura, em especial organizando greves, fica ainda mais evidente que o sindicalismo oficial não garantia por si só o controle total sobre as mobilizações operárias.

Embora o predomínio das greves por empresas seja visível após pesquisarmos um maior intervalo de tempo (foram 250 greves por empresa contra 224 por categoria no período 1945-1964), não é de estranhar que as greves por categoria tenham sido destacadas em muitas pesquisas sobre o tema. Como o impacto social, político e econômico dessas paralisações é maior, sua repercussão também tende a ser ampliada, sendo mais fácil localizar seus registros nos jornais diários, por exemplo. E os números de greves por categoria também foram expressivos ao longo de todo o período, ampliando-se substancialmente na fase final.

Não se pode menosprezar a importância de algumas greves que reuniram diversas categorias, como a "greve da paridade" ou as "greves da legalidade". Em relação ao movimento pela legalidade, é bom destacar que envolveu diversas categorias que entraram em greve sem comando unificado. Portanto, os números totais de greves daquele ano de 1961 foram bastante ampliados em função da presença de 25 greves (de um total anual de 56), em apoio à saída constitucional da crise aberta pela renúncia de Jânio Quadros. O mais significativo é que no ano seguinte, apesar da inexistência de evento semelhante, o número de greves foi ainda maior. Especial atenção deve ser dada às 
greves explicitamente convocadas para serem gerais: a greve por um gabinete nacionalista (julho de 1962); a greve pela antecipação do plebiscito (setembro de 1962); e a greve de resistência ao golpe de março e abril de 1964. No Rio de Janeiro, todas alcançaram alto índice de adesão, pela organicidade das intersindicais na cidade (CPOS, PUA e CGT) e pela certeza da paralisação dos transportes, em especial dos trens.

Quanto à distribuição das greves entre os setores público e privado da economia, é muito difícil sustentar as interpretações de predomínio das paralisações no setor público, em razão das maiores garantias desses trabalhadores, ou mesmo de uma suposta tolerância das autoridades. No total, ocorreram 207 greves no setor privado, contra 63 no setor público, além das 85 greves em que estiveram envolvidos trabalhadores dos setores público e privado. Observamos que, mesmo na fase final do período estudado, quando várias empresas antes privadas foram estatizadas, o número de greves no setor privado é maior. Porém, as fartas evidências da repressão, discutidas mais adiante, contestam claramente qualquer interpretação sustentada na idéia de tolerância.

Na Tabela 3, sistematizamos essas informações.

Tabela 3

Greves por setor

\begin{tabular}{lccccc}
\hline Anos & Público & Privado & Ambos & N.D. & Totais \\
\hline 1954 & 3 & 10 & 1 & - & 14 \\
\hline 1955 & 4 & 12 & 2 & - & 18 \\
\hline 1956 & - & 15 & 5 & 2 & 22 \\
\hline 1957 & - & 12 & 2 & 2 & 16 \\
\hline 1958 & - & 6 & 1 & - & 7 \\
\hline 1959 & 4 & 21 & 6 & 1 & 32 \\
\hline 1960 & 13 & 12 & 8 & 2 & 35 \\
\hline 1961 & 9 & 31 & 13 & 3 & 56 \\
\hline 1962 & 7 & 30 & 20 & 4 & 61 \\
\hline 1963 & 15 & 38 & 19 & 5 & 77 \\
\hline 1964 & 8 & 20 & 8 & 2 & 38 \\
\hline Totais: & 63 & 207 & 85 & 213 & 76 \\
\hline
\end{tabular}


Já a Tabela 4 nos dá uma idéia sobre a natureza das demandas expressas pelas pautas de reivindicações dos grevistas. Consideramos as principais reivindicações de cada greve, e as computamos ano a ano, o que nos fez obter, obviamente, um número de reivindicações muito superior ao número de greves.

Tabela 4

Natureza das Reivindicações

\begin{tabular}{|c|c|c|c|c|c|c|c|}
\hline Anos & Reajuste & Atraso & $\begin{array}{l}\text { Condições } \\
\text { de trabalho }\end{array}$ & Direitos & Política & Solidariedade & N.D. \\
\hline 1954 & 9 & - & 1 & 4 & 4 & 1 & 2 \\
\hline 1955 & 7 & 2 & 1 & 3 & 3 & 2 & 3 \\
\hline 1956 & 11 & 1 & 1 & 7 & - & 3 & 2 \\
\hline 1957 & 7 & 3 & 1 & 3 & - & 2 & 1 \\
\hline 1958 & 4 & 2 & - & 3 & 1 & - & - \\
\hline 1959 & 14 & 4 & - & 15 & 1 & - & 6 \\
\hline 1960 & 10 & 13 & 2 & 10 & 2 & 1 & 2 \\
\hline 1961 & 13 & 5 & 1 & 12 & 25 & 3 & 1 \\
\hline 1962 & 27 & 4 & 6 & 22 & 6 & 9 & 3 \\
\hline 1963 & 25 & 6 & 7 & 26 & 7 & 15 & 4 \\
\hline 1964 & 7 & 8 & 3 & 21 & 1 & - & 5 \\
\hline Totais: & 134 & 48 & 23 & 126 & 50 & 36 & 29 \\
\hline
\end{tabular}

Houve, de fato, um predomínio de demandas econômicas, de uma forma ampla, ou mais especificamente de propostas de reajustes salariais, nas pautas de reivindicações dos movimentos grevistas, a não ser nos últimos anos do período, em que cresceram as greves por direitos e, em menor proporção, aquelas por motivação política e por solidariedade (indicando elevação do grau de politização do movimento). As pautas mais recorrentes costumavam incluir a demanda por reajuste salarial, acompanhada, entretanto, de outras reivindicações, como as concernentes às condições de trabalho, ou aquelas que se referiam a direitos já garantidos em acordos coletivos anteriores ou em dispositivos legais, desrespeitados pelos patrões. A distinção entre reivindicações salariais e demandas por direitos muitas vezes se confundia em pautas como as que 
pleiteavam salários profissionais (pisos salariais por categoria) e planos de cargos, pois se tratava de demandas por novos direitos, mas que implicavam reajustes salariais. Por isso computamos esse tipo de demanda nas duas rubricas. Havia também greves cuja demanda era o pagamento de um reajuste ou outro benefício já conquistado, por lei ou negociação, mas que os empresários recusavam-se a conceder, aqui também computadas como por direitos.

Muitas vezes, os trabalhadores paravam para reivindicar o pagamento de reajuste já conquistado, como na mobilização dos trabalhadores em carris (bondes), em setembro de 1960. Diversas também foram as greves por atrasos de pagamento, como a parede dos operários da fábrica de móveis L. Martins, em janeiro de 1961; dos rodoviários, em janeiro de 1963; ou dos trabalhadores da Panair, em dezembro daquele mesmo ano. Atrasos e descumprimentos de decisões judiciais nem sempre apareciam como reivindicações únicas e era comum que se somassem a outras demandas econômicas não necessariamente vinculadas ao reajuste salarial, em diversos movimentos.

Torna-se importante, portanto, salientar que as pautas econômicas dominantes não se incompatibilizavam com demandas políticas ou por garantia de direitos contra as decisões da própria Justiça do Trabalho. Pelo contrário, muitas greves incluíam várias demandas de natureza distinta, e mesmo em demandas primariamente econômicas, colocava-se muitas vezes a dimensão do enfrentamento político. Um bom exemplo é o grande número de greves, nos anos 40 e 50, contra a cláusula da assiduidade integral, mecanismo que era incluído pela Justiça do Trabalho nas convenções coletivas, atrelando a concessão do índice de reajuste e de outras cláusulas definidas ao comparecimento (sem atrasos) integral dos trabalhadores, podendo haver um recuo ao salário pago no ano anterior em cada mês em que se registrasse atraso ou falta por parte de um trabalhador.

Em todos esses casos, confirma-se a hipótese de que direitos instituídos em lei, ou garantias das convenções coletivas, respaldadas pela Justiça do Trabalho, não significavam conquistas materiais às quais os trabalhadores tivessem acesso líquido e certo. Era preciso muitas vezes recorrer às greves para garantir direitos conquistados, enfrentar a insistência dos patrões em descumprir acordos, ou denunciar a iniqüidade de decisões judiciais. ${ }^{10}$ Esse constitui um dos elementos importantes para avaliarmos a superficialidade das análises que imputam às supostas conquistas materiais advindas da legislação trabalhista uma amplitude tal que seriam capazes de sustentar pactos políticos de longo fôlego entre a classe trabalhadora e os governantes em torno da proposta trabalhista. ${ }^{11}$ 
O grau de politização embutido em determinadas greves por demandas econômicas, em especial no setor de serviços, também merece comentários. Em Santos, Fernando da Silva já havia observado como os trabalhadores do porto acompanharam o desfecho de muitas de suas greves com uma ação do governo, que acoplava o atendimento do pleito de reajuste a uma subseqüente compensação da empresa através de um aumento proporcionalmente maior das tarifas. Com a recorrência dessa saída, passaram a incluir em sua pauta a demanda de desvinculação entre reajuste salarial e aumento de tarifas, denunciando a "indústria da reivindicação" ${ }^{12}$ Também é possível localizar exemplos similares em movimentos no Rio de Janeiro. Nos anos 60, os bancários percebendo que suas conquistas oriundas de greves nacionais da categoria acabavam sendo compensadas para os banqueiros, pelo governo Goulart, que autorizava em seguida movimentos favoráveis aos bancos privados na Carteira de Redescontos do Banco do Brasil, agiram para exigir o fim dessas compensações, no bojo de um movimento maior pela reforma do sistema financeiro nacional e se utilizaram da tática de parar alguns bancos de cada vez, sem aviso prévio, como forma de dificultar tais articulações. ${ }^{13}$

É preciso registrar com destaque aquelas greves que, embora menos numerosas, foram motivadas por condições de trabalho. Estas se constituem em nítida demonstração de que o movimento organizado, quer através do sindicato, ou das OLTs, não desconhecia os problemas do dia-a-dia da exploração no chão da empresa. Algumas dessas paradas se dão na situação drástica do protesto contra a morte de companheiros em acidentes. Foi o caso da greve dos têxteis da Mavilis e Bonfim, em fevereiro de 1955, que pararam por um dia para acompanhar o enterro de um trabalhador acidentado na fábrica.

Atentar para as condições de trabalho poderia ser até mesmo uma chave para mobilizar os trabalhadores para demandas mais gerais. Assim parecia entender o líder ferroviário Batistinha, que explicou em entrevista a razão da representatividade das diretorias sindicais de que participou, destacando sua atenção para os problemas cotidianos do ambiente de trabalho e a ponte entre essas demandas específicas e as lutas políticas mais amplas. A citação, embora longa, se justifica, por mostrar este elo na trajetória do grupo dirigente representado por Batistinha, nos dez anos que se seguiram a 1954, ano da primeira gestão desse grupo cuja direção era dada por militantes comunistas:

O salário era baixíssimo, a exploração do trabalho era muito grande, a "hora de trabalho" era excessiva, e nós conseguimos dar uma virada muito grande em pouco tempo. Então atingimos o econômico, o trabalhador ficou satisfeitíssimo 
com a gente e tinha alguns que diziam o seguinte: "eu não concordo com as idéias do pessoal, mas este pessoal é um burro de carga para trabalhar para a gente". Votava na gente achando isso. Assim, eles continuavam dizendo: "eu não gosto desse negócio de comunista, mas não sei o quê, mas esse pessoal é um burro de carga de trabalhar para a gente". E éramos mesmo. Nós estávamos com uma responsabilidade muito grande e em curto espaço de tempo a classe sentiu a melhoria das condições de trabalho. Nós começamos a exigir bebedouro, começamos a exigir limpeza nos locais de trabalho ... a quantidade de companheiros que adoeciam de tuberculose era muito grande. Nós exigimos reparos de telhas quebradas nas oficinas, essas coisas, antes da CIPA! Nós já tínhamos essa preocupação com os locais de trabalho. E os trabalhadores realmente sentiram bem, então passaram a ficar predispostos às nossas outras idéias políticas, outras idéias. O cara dizia: "não, não topo, não gosto, mas o cara trabalha para a gente e tal não sei quê". A coisa era nesse sentido. ${ }^{14}$

A existência de diversas greves por reivindicações basicamente políticas é explicada pela ocorrência, anteriormente mencionada, de greves intercategoriais, gerais e/ou nacionais, com destaque para as "greves da legalidade", de 1961. Além das greves gerais, greves nacionais de categorias como a dos bancários em 1962, contra uma proposta de reforma do sistema financeiro em tramitação no Congresso, também tiveram pauta eminentemente política.

Voltando às greves por solidariedade, elas também constituem evidência de que o motor da mobilização nem sempre dizia respeito às reivindicações de natureza material. Tais greves demonstram ainda que os sentimentos de pertencimento a uma classe e de representatividade das organizações sindicais eram expressivos no período. A solidariedade poderia se fazer em termos de apoio a um companheiro de trabalho injustamente demitido. Foi o caso, por exemplo, da greve dos empregados da Usina Santa Luzia, em setembro de 1963. Já no estaleiro Verolme, numa greve que durou nove dias, 1.800 operários pararam contra a demissão de oitenta companheiros, naquele mesmo ano de 1963. Se o movimento na Verolme ilustra o uso da greve para garantir o emprego, em outros movimentos a solidariedade representava a defesa de direitos sindicais, pois na Santa Luzia os demitidos eram representantes sindicais.

A defesa da representação sindical no local de trabalho moveu, como reivindicação principal ou associada a outras, várias paredes, não apenas em reação a demissões, como aconteceu na greve dos operários navais da Costeira e do Lóide, em junho de 1963, quando milhares de trabalhadores pararam reivindicando o reconhecimento dos delegados sindicais. As reivindicações sa- 
lariais em certos casos demandavam, para sua apresentação, a defesa dos direitos de organização, como na greve da Fábrica Nacional de Vagões, em fevereiro de 1962, motivada pela demissão do delegado sindical, no momento em que este apresentava as reivindicações da comissão de trabalhadores da fábrica. Trata-se de mais um indicador de que a legislação sindical não bastava para conter o impulso de organização no local de trabalho e o sindicato oficial não era o único espaço de organização.

Por direitos de organização também eram feitas greves que enfrentavam as práticas de controle do Ministério do Trabalho sobre os sindicatos, como na greve dos ferroviários da Leopoldina, em outubro de 1954, em que 14 mil trabalhadores pararam por reivindicações salariais e pelo fim da intervenção no sindicato.

Além disso, as greves por solidariedade demonstram que a estrutura sindical não conseguiu compartimentar completamente as lutas da classe trabalhadora nas gavetas estanques das categorias. Muitas foram movidas, mostrando que, para além dos organismos intersindicais, criados muitas vezes em meio às greves, o impulso das demonstrações concretas de unidade na luta atravessava os mais diversos momentos. Elas podiam ocorrer dentro de uma mesma categoria, em regiões diferentes. Foi o caso da greve dos petroleiros do Rio, em novembro de 1963, em apoio à greve dos petroleiros de Guarapuava. Ou da greve nacional dos ferroviários, em solidariedade aos companheiros da Sorocabana, naquele mesmo ano. Havia também as greves em solidariedade às lutas de trabalhadores de outras categorias do mesmo ramo, como a greve de ferroviários e motorneiros em apoio aos motoristas de ônibus, em março de 1963. Ou ainda a greve dos marítimos, em apoio aos portuários, em novembro daquele mesmo ano. Mas, as solidariedades se teciam também entre trabalhadores de categorias muito diversas, como na greve dos ferroviários da Leopoldina, em 1960, em apoio à greve dos funcionários da Prefeitura de Macaé.

Havia greves de solidariedade com proporções bem maiores, como foi o caso das paralisações e manifestações de apoio de diversas das mais importantes categorias cariocas em solidariedade à greve da Paridade, de novembro de 1960. Ou da greve contra a demissão do Comandante Paulo Mello Bastos pela Varig, em junho de 1963, convocada pelo CGT, num chamado nacional que foi atendido não apenas pelos aeroviários e aeronautas, mas também por ferroviários, petroleiros, marítimos e diversas outras categorias. Afinal, Mello Bastos era Presidente do Sindicato dos Aeronautas, bem como da Federação dos Trabalhadores em Transportes Aéreos e Secretário do CGT. ${ }^{15}$ 
Em relação aos resultados dos movimentos, é difícil estabelecer com precisão, a partir das fontes, os momentos em que as greves foram avaliadas como vitoriosas pelos grevistas. A subjetividade dessa avaliação poderia levar a que greves que enfrentaram dura repressão fossem avaliadas como politicamente vitoriosas se chegavam ao fim de forma unificada, mesmo que conquistando apenas parte das reivindicações. Por sua vez, greves dobradas pela força dos patrões e da repressão estatal poderiam ser vistas como derrotas, ainda que ganhos na pauta fossem obtidos. A sensibilidade da imprensa para esses fatores nem sempre era apurada, o que dificulta ainda mais uma avaliação. Apenas a título de exemplificação, computamos os dados do ano de 1962 para tentar uma aproximação com as avaliações de vitória ou derrota dos movimentos grevistas. Em 1962, localizamos 16 greves entendidas como vitoriosas, correspondentes a apenas $26,2 \%$ do total de paralisações daquele ano. Naturalmente, registros mais detalhados nos possibilitariam avaliar com maior precisão esse aspecto das greves.

Os dados sobre ciclos de greves, dimensões, características das paralisações e de suas pautas de reivindicações são fundamentais para localizarmos com maior precisão os padrões desses movimentos, bem como seu impacto social. Não bastam, porém, para explicar as greves. É preciso recorrer a aspectos "externos" na busca de análises que superem a descrição, ainda que não a excluam.

Explicar essas fases, características e variações das greves é tarefa que exige a mobilização de diversos fatores de análise. São recorrentes as análises de greves que buscam explicação para as mobilizações dos trabalhadores nos aspectos mais diretamente econômicos, como: relação salários/custo de vida, nível de emprego/desemprego e relações de trabalho no chão de fábrica. ${ }^{16}$ Não cabe aqui investigar a fundo esses indicadores, porém devemos ter em conta pelo menos um quadro geral para situar a discussão.

Sobre a questão salarial, não é de estranhar que a motivação principal das greves no período fosse o reajuste. Tomando-se o salário mínimo como padrão de comparação, os anos de 1954 até 1958 constituíram a fase de mais elevado poder de compra do salário mínimo naqueles anos. Mas a tendência de queda seria retomada nos anos seguintes, sendo possível perceber que em 1963 1964 o valor do salário mínimo era inferior ao do momento de sua criação. ${ }^{17}$

Já o custo de vida manteve-se em alta durante todo o período. A partir de 1951, os dados sobre a taxa de inflação mostram uma tendência de alta, 
que se acelerará a partir de 1959 , atingindo taxas de cerca de $80 \%$ ao ano às vésperas do golpe militar de $1964 . .^{18}$

Recuperar e defender o poder de compra dos salários seria assim um fator explicativo importante para entendermos os ciclos de greves do período. O crescimento acentuado no número de paralisações entre 1959 e 1964 possui aí uma de suas explicações. Mas, certamente não a única.

Quanto ao nível de emprego/desemprego, toma-se como padrão que o crescimento dos níveis de desemprego dificulta as mobilizações e os confrontos com os patrões por parte dos trabalhadores. Não há indicadores confiáveis para todo o período, mas vale atentar para o fato de que a maior parte daqueles anos é de expansão da atividade econômica, exceção feita justamente para a fase dos primeiros anos da década de $1960,{ }^{19}$ quando a crise pode ter gerado menor segurança no emprego. $\mathrm{O}$ que, como vimos, não foi suficiente para frear as mobilizações, mesmo no setor privado, sempre mais instável do ponto de vista das garantias do emprego. Há que se levar em conta também o peso do estatuto da "estabilidade no emprego", que tanto estimulava a rotatividade da mão-de-obra empregada há poucos anos na empresa, quanto garantia maior segurança para os trabalhadores com mais de dez anos de tempo de serviço na mesma firma, o que poderia conferir maior poder de barganha e autonomia para liderar paralisações.

O grande número de greves por empresa, algumas motivadas por questões tipicamente relacionadas às condições de trabalho, parece indicar que havia tensões importantes no que diz respeito à submissão dos trabalhadores às regras da organização do trabalho nas firmas. Entretanto, o fato de esse tipo de demanda ter sido sempre inferior às demandas salariais indica que não era esse um motor principal das greves. Fatores de natureza interna ao processo de trabalho em cada empresa nem sempre são detectáveis por balanços quantitativos como os aqui esboçados, e para melhor dimensioná-los seriam necessários estudos de caso mais detalhados de greves por empresas.

Seria, porém, muito simplista tentar explicar as greves apenas pelas questões de natureza econômica. Fatores do contexto político podem ser muito importantes para o entendimento dos ciclos de paralisações. Tomando-se o Estado como condensador dos conflitos sociais de sua época, podemos pensar no peso determinante dos interesses empresariais no posicionamento dos governos frente às mobilizações dos trabalhadores, não descartando, entretanto, as tensões decorrentes do modelo de administração de conflitos nos marcos da democracia representativa. A maior ou menor disposição para enfrentar as greves dentro do jogo democrático variou conforme os compro- 
missos políticos dos governantes com eleitores trabalhadores, bem como ante o peso das mudanças na conjuntura internacional. É fato que, no pós-1945, o governo Dutra foi aquele que menor preocupação demonstrou em ir além da repressão para coibir as greves, mantendo de pé a legislação repressiva do Estado Novo, enquanto a nova Constituição não era aprovada e antecipando-se à Constituinte - que embora tenha reconhecido o direito de greve, manteve intacta a estrutura sindical corporativista criada no primeiro governo Vargas - ao regulamentar de forma restritiva ao extremo o exercício da greve, além de ter se pautado pelas intervenções do Ministério do Trabalho nos sindicatos. Mas, os governos seguintes, mais comprometidos com o discurso trabalhista que lhes cimentaria caminho para o voto popular nas eleições, embora não lançassem mão sistematicamente das intervenções e da exigência do "atestado de ideologia" (suspensa no segundo governo Vargas), não desmontaram o aparato repressivo sobre as greves, mantendo de pé a legislação do governo Dutra e acionando sistematicamente a repressão policial, conforme analisado a seguir.

Porém, pensar o peso da política sobre as greves apenas pelo grau de repressão do Estado sobre os sindicatos seria, também, muito reducionista. Especialmente em se tratando de greves, é fundamental inverter o ângulo de abordagem e observar como os trabalhadores, com cada vez mais força conforme passavam os anos, procuravam interferir no processo político, buscando materializar não apenas seus direitos trabalhistas - que, como vimos, dependiam de muita luta para efetivar-se —, mas também a expectativa de ampliação das dimensões políticas e sociais de um regime que se pretendia democrático. É essa dimensão política, no sentido amplo, que se revela em movimentos cruciais para a defesa da democracia, como as greves pela legalidade, sustentando a saída constitucional, com a posse de João Goulart, a presença de demandas como o gabinete nacionalista e as reformas de base nas greves gerais convocadas pelo CGT, ou ainda a greve geral iniciada contra o golpe militar de 1964. Não há dúvida, nesse sentido, de que se os embates do período anterior ao golpe militar tiveram um desfecho autoritário, os trabalhadores e suas organizações empenharam-se, não apenas de forma retórica, mas com suas lutas, para preservar e ampliar a democracia.

Há um outro fator de natureza política do qual não se pode fugir para explicar os ciclos grevistas. Diz respeito à caracterização da linha política das direções e sua disposição para os enfrentamentos. Se as greves não foram conduzidas apenas pelo alto - pelas direções — é inegável que, quando estas se mostravam dispostas a dirigir mobilizações grevistas (fosse através dos sindi- 
catos ou de organizações paralelas), as chances de surgimento de greves se ampliavam. Por isso, nos períodos em que os comunistas, aliados à esquerda dos trabalhistas, estiveram à frente de sindicatos - como em 1946 e, particularmente, entre fins dos anos 50 e 1964 - a disposição política das lideranças sindicais somou-se aos demais fatores e teve peso expressivo para explicar o crescimento no número de greves e o alargamento político do horizonte de demandas.

O que não quer dizer que direções comunistas atuassem apenas conforme a linha do partido. No período em questão, há movimentos grevistas que confirmam essa relativa autonomia dos sindicalistas comunistas em relação à direção do partido. Foi o caso da greve dos ferroviários da Leopoldina contra a proposta de decretação do Estado de Sítio por parte de Goulart, em 1963. Segundo Batistinha, a greve contrariava a linha defendida pela direção do partido, mas ainda assim foi feita, segundo ele porque "Eu era do Partido Comunista da Leopoldina... ". ${ }^{20}$

\section{POLÍ́CIA}

Pode-se observar que a vigilância e repressão policial sobre a classe trabalhadora, em especial no aspecto de suas organizações e formas de luta, foi uma atribuição cada vez mais enfatizada nos regulamentos policiais, desde a década de 1890. Assim, o regulamento policial de 1900 já definia a especificidade e a importância das atribuições de "polícia política", quando definia competências: "a polícia política compete privativamente ao Chefe de Polícia, de acordo com as ordens e instruções do Ministério da Justiça”. ${ }^{21}$ Por regulamento de 1907, tais competências seriam exercidas por um grupo especializado de policiais, reunido no Corpo de Investigação e Segurança Pública. Em 1920, na esteira das grandes mobilizações operárias dos anos anteriores, como a greve geral paulistana de 1917 e a insurreição operária abortada pela espionagem policial no Rio de Janeiro, em 1918, o nível de especialização da ação policial se aprofunda e a tarefa de conter o movimento operário se explicita. O Corpo de 1907 deu lugar à Inspetoria de Investigação e Segurança Pública. A Inspetoria foi definida como "instituição autônoma, subordinada ao Chefe de Polícia", competindo-lhe entre outras atribuições "a manutenção da ordem pública". Contava com oito seções, entre elas a de "ordem social e segurança pública", única que não se submetia a subinspetores, estando "sob a responsabilidade imediata e direção exclusiva da Inspetoria”. Entre as atribuições 
estavam: "zelar pela existência política e segurança interna da República ... desenvolver a máxima vigilância contra quaisquer manifestação ou modalidade de anarquismo violento e agir com solicitude para os fins da medida de expulsão de estrangeiros perigosos".

Desde então, as greves estiveram entre as principais preocupações policiais. No Direito Público brasileiro, o tratamento ao fenômeno social greve oscilou entre considerá-la um delito e um direito. O Código Penal de 1890 estipulava a pena de prisão celular de um a três meses para quem "causar ou provocar a cessação do trabalho, para impor aos operários ou patrões aumento ou diminuição de serviço ou salário” (art. 206). Uma campanha movida pelo Partido Operário, organizado na Capital Federal, levou o governo a suprimir a norma do art. 206 do Código Penal, através do decreto $\mathrm{n}^{\circ}$ 1.162, de 12 de dezembro de $1890 . .^{22}$

Nas memórias dos militantes da Primeira República, o braço da polícia que mais arrepios causava à lembrança era a $4^{\text {a }}$ Delegacia Auxiliar, criada em 1922, em plena conjuntura de efervescência política da irrupção do tenentismo e no ano de fundação do PCB. A $4^{a}$ Delegacia possuía as mesmas seções da inspetoria, mas a seção de Ordem Social e Segurança Pública passou a se chamar Seção de Ordem Política e Social.

É quase um lugar comum, nas análises produzidas nas últimas décadas, afirmar que, se na República Velha a "questão social" (leia-se movimentos dos trabalhadores) era um caso de polícia, com a Revolução de 1930 ela passou a ser tratada como um caso de política, numa referência ao conjunto de políticas sociais implementadas pelo $1^{\underline{0}}$ Governo Vargas. Porém, nunca é excessivo lembrar que a "questão social", apesar de seu novo encaminhamento político no pós-1930, não deixaria de ser encarada pelos governos posteriores como também e ainda um caso de polícia. Afinal, em 1933, a legislação varguista aperfeiçoou o aparelho repressivo, substituindo a $4^{a}$ Delegacia Auxiliar pela Delegacia Especial de Segurança Política e Social — DESPS. Delegacia independente da polícia administrativa e judiciária, a DESPS estava diretamente subordinada à Chefia de Polícia, sendo suas atribuições determinadas por um regulamento especial. Dividia-se em três seções: segurança política, segurança social, e armas e explosivos.

Ao longo daqueles anos, as greves voltaram a ser alvo de uma legislação que restringia ao máximo seu exercício, chegando mesmo a criminalizá-las, na fase mais abertamente autoritária. A Lei n. 38, de 4 de abril de 1935, da Segurança Nacional, chamada pelos sindicalistas de "Lei Monstro", classificava a greve como delito no funcionalismo público e nos serviços inadiáveis. As leis 
do Estado Novo seriam ainda mais rigorosas. O Código Penal de 1940 continuou considerando a greve como um crime, mas sem o detalhamento do decreto anterior. Tratada a greve como delito, as justificativas legais para o aperfeiçoamento do aparelho policial repressivo e de sua ação contra os sindicatos estavam postas.

No fim do Estado Novo, em meio a diversas reformas que tinham por objetivo garantir uma longa duração para o aparato institucional criado durante o regime ditatorial, ainda que este perecesse, a polícia do Distrito Federal foi federalizada, ao mesmo tempo em que se criava um nível de especialização ainda maior da polícia política em relação ao restante do organismo policial, além de instituir-se um modelo e órgão de conexão para todas as Delegacias de Ordem Política e Social que se espalhavam pelos estados. Isto se deu com a criação, em 1944, do Departamento Federal de Segurança Pública, que incluía em seu organograma atribuições nacionais e locais, das quais nos interessam mais diretamente as exercidas pela Divisão de Polícia Política e Social - DPS.

Após certa indefinição legal no ano de 1945, a DPS permanecerá ativa até a transferência da capital para Brasília, em 1960, quando suas atribuições são inicialmente transferidas para o estado da Guanabara, recém-criado, onde se constituirá, em 1962, um Departamento de Ordem Política e Social.

Nesse período, uma legislação extremamente questionada garantiu o guarda-chuva legal para a ação policial na repressão às greves. Tendo participado o governo brasileiro da Conferência Interamericana sobre os Problemas da Guerra e da Paz, conhecida como Conferência de Chapultec, em fevereiro e março de 1945, acabou por ratificar decisões que consagravam direitos sociais, entre os quais o "reconhecimento do direito de associação dos trabalhadores, do contrato coletivo e do direito de greve". Em conseqüência do clima de redemocratização, a greve passou de delito a direito garantido pela Constituição em 1946. Porém, como vimos, utilizando-se da prerrogativa de governar por Decretos, conforme a Constituição de 1937, o governo Dutra antecipou-se em alguns meses à promulgação da Constituição e, através do Decreto-Lei no 9.070, de 13 de março de 1946, criou enormes barreiras legais ao exercício do direito à greve. Em síntese, o decreto reforçava o poder normativo da Justiça do Trabalho ao submeter obrigatoriamente os dissídios à conciliação prévia e limitava a possibilidade de greves legais à situação em que, obedecidos todos os prazos e trâmites que os sindicatos tinham que cumprir naquela instância, julgado o dissídio, os empregadores não cumprissem suas cláusulas. Ainda assim, isso só poderia ocorrer entre as categorias urba- 
nas, do setor privado, cujas atividades não estivessem incluídas na extensa lista de "atividades fundamentais". Funcionalismo, trabalhadores rurais e trabalhadores em serviços urbanos, comércio de gêneros e indústrias básicas ou "essenciais à defesa nacional" estavam liminarmente proibidos de ir à greve. As punições para os grevistas variavam da demissão a penas criminais.

Enquanto existiu a DPS a vigilância e repressão ao movimento organizado dos trabalhadores foi exercida por um órgão interno especializado: o Setor de Fiscalização Trabalhista (a partir de 1955, chamado de Seção Trabalhista). Nos arquivos da repressão, os ofícios trocados entre investigadores e inspetores e entre eles e seus superiores, bem como os recortes de jornais diários e os relatórios de investigação, vêm sempre acompanhados do carimbo "Setor Trabalhista", ou apenas "Trabalhista”. As competências do Setor foram definidas a partir de 1946, quando uma portaria regulamentou o Serviço de Investigações. A ele competia "Organizar e manter um serviço permanente de vigilância especializada do ponto de vista político-social, cumprindo-lhe, outrossim, fazer realizar as investigações determinadas.... Portaria Reservada subseqüente definia que ao Setor de Fiscalização Trabalhista (St. 1) competia "proceder a investigações atinentes a massa trabalhista em geral".

Com base na documentação interna do órgão e em algumas referências a depoimentos de militantes, é possível recuperar um pouco da forma de atuação da DPS junto aos sindicatos, com destaque para os momentos de greve.

Não foram poucas as modalidades de intervenção da polícia política sobre o movimento sindical no período em questão. No que diz respeito à vigilância, por exemplo, havia um compromisso permanente com a identificação das direções. No governo Dutra, um dos instrumentos básicos de controle sobre os sindicatos foi a exigência do atestado de ideologia, documento expedido pela polícia política atestando a ficha limpa naquele órgão, para qualquer candidato a cargo de direção nos sindicatos. Entende-se, portanto, a utilidade de a DPS emitir, por solicitação do Ministério do Trabalho, listas de diretores dos sindicatos, no momento de sua candidatura ou eleição, com referências aos antecedentes de cada um nos órgãos policiais.

Vargas interrompeu a exigência do atestado de ideologia para os candidatos às direções sindicais. A polícia política, entretanto, continuou a enviar tais listas ao Ministério do Trabalho, sem qualquer modificação em seu formato, ainda que com freqüência menor. Pesquisando dossiês relativos a 109 sindicatos e 13 confederações, Luciana Lombardo encontrou 540 acusações a 301 militantes sindicais, em listas desse tipo. ${ }^{23}$ Tabulando as "acusações" que acompanhavam cada nome, chegou à conclusão de que a orientação antico- 
munista é um elemento norteador da ação repressiva do Estado. Das 540 acusações contra sindicalistas trabalhadas, constatou-se que 242 delas são de comunismo. No entanto, apenas oitenta dos acusados são apontados como membros efetivos de células do Partido Comunista, sendo o dobro o número de elementos, genericamente tachados de "comunistas" ou "esquerdistas" (162 acusações). Os informes de agentes infiltrados ou delações não se baseavam na atuação das pessoas no Partido, legal ou clandestino, mas nos discursos, posicionamentos e nos subjetivos indícios que os líderes sindicais deixavam perceber.

A segunda categoria mais encontrada é a de grevistas ou "agitadores", pessoas que dentro ou fora dos sindicatos oficiais, de alguma forma, participam mais ativamente de suas atividades e manifestações, com 149 acusações, o que mostra que ser militante ativo do movimento operário constituía um “crime” político. Somando essas duas categorias, há o rótulo mais corrente encontrado nas anotações policiais, o de "agitador comunista".

Nos dossiês sobre sindicatos ou sobre movimentos grevistas, encontramos, além dessas listas nominais, uma série de registros sobre a atuação da polícia, manifestos e outros documentos sindicais transcritos, além de relatórios a respeito de atividades ou entidades específicas, bem como inúmeros recortes de jornais, minuciosamente agrupados por tema, órgão de imprensa e data.

Até os primeiros anos da década de 1960, é nítido o esforço da polícia política em caracterizar a estreita ligação das entidades e movimentos dos trabalhadores com aquilo que na sua visão é a maquinação ardilosa dos comunistas, sempre cumprindo fielmente as orientações de Moscou. É o que encontramos nos relatórios do Chefe do Setor Trabalhista que explicam as entidades intersindicais para seu superior, responsável pela DPS. Em memorando contendo informações gerais sobre o Pacto de Unidade e Ação - PUA, dos trabalhadores em transportes, datado de 4 de setembro de 1962, afirmase que ele "atualmente vem dirigindo no seio dos trabalhadores deste estado, todos os movimentos grevistas de caráter político, tem a sua fonte de origem no Partido Comunista do Brasil [refere-se ao PCB], pela necessidade que sempre teve esse partido de unir, em um só bloco, os trabalhadores da classe dos transportes". ${ }^{24}$

O mesmo sentido teve outro memorando próximo no tempo, datado de 24 de outubro de 1962, dedicado à caracterização do Comando Geral dos Trabalhadores - CGT. No documento, também assinado pelo responsável pelo Setor Trabalhista e enviado ao responsável pelo DPS, o CGT é assim definido: 
1 - O COMANDO GERAL DOS TRABALHADORES ou simplesmente CGT é uma entidade de inspiração comunista, criada no seio do sindicalismo brasileiro em setembro de 1961, após a realização da greve de caráter político levada a efeito, nessa época, no país ... tendo como tarefa precípua transformar-se, talvez por ocasião do IV Congresso Sindical Nacional - a realizar-se no próximo ano - na Confederação Geral dos Trabalhadores ou CGT, conforme a representatividade que venha a ter no meio da massa sindical, passando, então, a atuar como uma verdadeira Central Sindical entidade máxima do sindicalismo de esquerda, cuja criação sempre constitui uma das tarefas primordiais de todos os PP.CC.

Acentuando o caráter externo à classe, e ao país, da atuação dos comunistas, o documento qualifica os dirigentes do CGT como "quase todos comunistas" e explica a existência de filiados a outros partidos como resultado da intenção do PCB de penetrar no governo e de trazer os setores operários filiados a outros partidos para o seio do comunismo. Os vínculos internacionais do PCB se traduziriam na filiação "informal” do CGT à Federação Sindical Mundial.

Tais vínculos internacionais seriam acentuados pela listagem dos representantes de entidades estrangeiras presentes a eventos sindicais nacionais, ou pela suposição de visitas não oficiais, pois segundo o documento: "tem-se notícia que outros elementos, principalmente cubanos, têm contato com os meios sindicais comunistas no país, principalmente com o Sindicato dos Bancários, cujos dirigentes, inclusive, já estiveram em Cuba onde receberam instruções de como procederem para o auxílio à Revolução".

A caracterização das organizações e movimentos dos trabalhadores como derivadas da infiltração comunista no seio da classe, com ênfase na origem externa das diretrizes comunistas, ganha tom mais pessoal quando nos aproximamos das identificações que a polícia política fazia dos militantes e dirigentes sindicais. É o caso de um informe a respeito de investigação sobre as atividades suspeitas de um militante marítimo, datado de 1959:

Irineu josé de souza, marítimo, ex. Deputado Estadual do PSB, elemento da direção do Partido Comunista com escritório no Edifício Ajax em Niterói pendurou uma faixa na frente da Frota, em Niterói, anunciando que o Russo seria o idioma do futuro. Quem quisesse aprender fosse ao Palácio do Comércio, sede do PSB, que seria ensinado gratuitamente. Mandei agente para lá. - Os professores são russos. A freqüência é composta em $95 \%$ de elementos operários e es- 
tudantes. Lições de russo, muito poucas. Doutrinação e ensinamento de sabotagem e preparação de monitores é o que ali se pratica. ${ }^{25}$

Militantes mais conhecidos possuíam extensa lista de entradas nos arquivos da Polícia Política. Estas poderiam significar autos de prisões, informes como o acima reproduzido, ou documentos apreendidos em poder dos militantes quando de ações policiais. O sapateiro Gervásio Telles, que foi Secretário Geral do seu sindicato nos anos 50, possuía 22 registros em sua ficha na polícia política, apenas entre 1953 e 1957. Ali se registraram prisões, como em 1952, por sua participação em um piquete de greve; referências a declarações suas aos jornais comunistas; participação em assembléias de outras categorias; assinatura de manifestos, como o da "Campanha Cívica de Mobilização Eleitoral”, em 1954; além da participação na delegação brasileira a Congressos Sindicais internacionais. ${ }^{26}$

Outro exemplo é o do já citado Demisthóclides Baptista, principal líder dos ferroviários da Leopoldina, Deputado Federal em 1962, um dos mais ativos dirigentes sindicais comunistas da época que também contava com dezenas de registros nos fichários das polícias políticas. Apenas para ficarmos com alguns exemplos, podemos reproduzir as anotações de um documento que resgatava seu "histórico", produzido quando da greve da paridade, em 1960:

DEMISTHÓCLIDES BATISTA — ... ferroviário, que residia na rua Sampaio Fer$\mathrm{raz}, \mathrm{n}^{\mathrm{0}}$ 52, figura aqui registrado com os seguintes antecedentes - Elemento agitador da classe ferroviária, presidente do Sindicato dos Trabalhadores em Empresas Ferroviárias. Embora pertencente ao PSB, é elemento de confiança dos comunistas da Estrada de Ferro Leopoldina Railway, onde trabalha e exerce suas atividades subversivas. Tem dado várias entrevistas ao matutino comunista Imprensa Popular na qualida digo qualidade de Presidente da Classe, abordando várias reivindicações. No dia 11 de março de 1954, em virtude de uma nota publicada no jornal Última Hora sobre a readmissão de vários comunistas pelo então Diretor da Leopoldina, inclusive o já conhecido agitador e comunista militante JOÃO BATISTA LOBO SARMENT, fez publicar um manifesto em favor dos comunistas ... Como presidente da referida entidade vem comparecendo em todas as assembléias de caráter subversivo realizadas em outras entidades de classe digo clandestinas, inclusive a que se efetuou no Sindicato dos Empregados no Comércio Hoteleiro e Similares do Rio de Janeiro, quando foram traçados planos dos festejos de $1^{\circ}$ de Maio de 1954, principalmente a concentração do Campo de São Cristóvão. Ultimamente, com a decretação do novo salário mínimo, 
vem agitando a classe ferroviária para lutar em favor do mesmo, sem no entanto, procurar compreender que atualmente os trabalhadores da Leopoldina são servidores autárquicos.

Em 28-9-954, foi recolhido á Sala de Detidos, à disposição do Sr. Diretor desta Divisão, sendo posto em liberdade no dia imediato, tendo sido processado no Cartório desta DPS, como incurso nas penas do artigo 201 C.P. c/c o art. 14, item I do Decreto-Lei no 9070, de 15-3-946. Em 9-11-960 foi recolhido a Sala de Detidos desta Divisão, aguardando julgamento a disposição da distribuição. Em 10-11-960 foi posto em liberdade com a guia assinada pelo inspetor Manoel. ${ }^{27}$

Em entrevista concedida nos anos 80, Batistinha se refere a diversas das suas passagens pela polícia, como nas greves de 1954, 1957 e na greve da paridade de 1960 (em que marítimos, portuários e ferroviários fizeram um movimento conjunto pela extensão a funcionários civis da União de reajuste anteriormente concedido aos militares) e, quando perguntado sobre a duração de uma delas afirma: "Fui preso tantas vezes que não me lembro a data certa". A certeza da prisão nos momentos de greve o fazia, até mesmo, utilizar a ação policial a favor dos movimentos, explorando a repercussão do fato junto à categoria, como em 1957, quando foi preso na gare de Barão de Mauá, no momento do início da greve. Segundo ele, "contava com aquela prisão. A concentração ferroviária era em Barão, eu saindo preso sabia que a massa ia reagir mesmo. Paramos na base da emoção”. A tática era usada também para obter repercussão da greve junto à opinião pública. Batistinha "normalmente ficava no sindicato, pois no caso de ser preso a repercussão era maior. Usávamos este método". ${ }^{28}$

Tomando por exemplo os dossiês sobre o movimento grevista nos anos 50 e 60, é possível perceber que o "Setor Trabalhista" produzia boletins reservados de seus investigadores para os inspetores dando conta de tarefas cumpridas num dia de trabalho, comunicados e informes com balanços dos movimentos em curso, produzidos pelos inspetores e enviados para o chefe do Setor, além de eventuais comunicados do Chefe do Setor para o Diretor da DPS. Nesses documentos, encontramos o modo de operação para monitorar, evitar ou reprimir greve. Acompanhamos alguns casos específicos.

Havia formas de atuação mais simples, em que a greve era evitada ou suspensa pela simples presença da autoridade policial. Certos registros, porém, demonstram a existência de intervenções policiais bem menos "tranqüilas". Na greve da paridade, em 1960, na noite da véspera da eclosão do movimento a polícia invadiu as sedes de sindicatos envolvidos e prendeu 57 militantes, 
que ficaram presos por mais três dias, praticamente toda a duração do movimento. Notícia do Jornal do Brasil, de 11 de novembro de 1960, recortada pelos policiais, assim resume o episódio:

Contaram os grevistas que estavam em seus sindicatos às $22 \mathrm{~h} 30 \mathrm{~m}$ do dia 7 quando surgiram policiais com bombas de gás, metralhadoras e revólveres para prendê-los, dizendo ter ordem para isso do Ministro Armando Falcão. Na madrugada do dia 8, os presos foram levados da Delegacia de Ordem Política para o Comissariado do Alto da Boa Vista, onde prestaram depoimento. No dia seguinte, seguiram para o Depósito de Presos. Afirmaram que não foram espancados porque os policiais também estão interessados na paridade, que elevará os seus salários. ${ }^{29}$

O juiz, que atendeu a despacho dos advogados dos marítimos, considerou as prisões efetivadas pela DPS como ilegais. Precavidos, os líderes do movimento já haviam impetrado um habeas corpus preventivo, para evitar a sua própria prisão e, em salvaguarda bastante comum na época, constituíram ao todo três comandos e quatro comissões para liderar a greve, cada uma com sede em uma entidade, trabalhando sempre com a eventualidade da queda de algum(ns) desses comandos. A polícia política, por sua vez, identificou cada comando, seus componentes e seu local de reunião.

A greve da paridade, entretanto, prosseguiu e foi vitoriosa, apesar do esforço policial em contrário. Nem sempre isto era possível. Foi o que se observou na tentativa de greve dos condutores de bondes da Light, em setembro de 1954, desmontada após a polícia ter invadido a assembléia da categoria que decretou a entrada em greve, na véspera de sua eclosão, levando presos todos os participantes da reunião. ${ }^{30}$

Cabe mencionar, ainda, que nem sempre a tarefa de reprimir as greves coube apenas à polícia política. Em movimentos de maior dimensão, outros setores do braço armado do Estado foram mobilizados. Um bom exemplo é o da própria greve da paridade. Voltando às fontes policiais, temos o relatório, datado de 11 de novembro de 1960, do investigador H. S. Leite Domingues, que informou ao Inspetor Vasconcelos, conforme solicitação deste, o ritmo de retorno ao trabalho após a assembléia que pôs fim à greve. $\mathrm{O}$ documento, porém, revela como foi intensa a vigilância e repressão na greve da paridade, relatando a presença de diferentes tropas nos locais de trabalho:

Informo a V. S., que, em companhia de Zezinho e Pinto, e, cumprindo vossa determinação, rondei os locais afetados pela recente greve, a fim de verificar co- 
mo se processaria a volta dos trabalhadores aos respectivos locais de trabalho. À 1,10 horas, na estação da Frota, não tinha lancha funcionando, estando o local policiado pelo DESP e Fuzileiros Navais - 1,35hs, na Central, o funcionamento dos trens era normal, estando o local policiado pelo Exército - 1,50hs, na Leopoldina, começava a normalização dos trens, tendo o $1^{\circ}$ saído à $1,30 \mathrm{hs}$, com os trabalhadores da Leopoldina voltando paulatinamente ao trabalho $-2,05 \mathrm{hs}$, no cais do Porto, desde a Francisco Bicalho até a Praça Mauá, sem nenhum movimento, estando o local policiado por tropas dos Fuzileiros Navais... ${ }^{31}$

As tropas das Forças Armadas chegaram a provocar mesmo enfrentamentos violentos com os grevistas no movimento pela paridade, como o que envolveu a tentativa de fazer correr um trem pelos trilhos da Leopoldina, com garantia de tropas do Exército, que acabou em enfrentamento com um piquete de oitenta homens, comandado pelo Tesoureiro do Sindicato dos Ferroviários da Leopoldina, Herval Arueira, assim relatada pelo jornal Diário de Notícias, em 10 de novembro de 1960:

Os soldados que viajavam no trem imediatamente saltaram e caminharam em direção aos grevistas, mandando que se afastassem. Como não foram atendidos, passaram a agredir os grevistas, a socos, pontapés e coronhadas, originando-se, entre os dois grupos um grande 'rififi'. Herval — por ser o líder — foi alvo das maiores sevícias por parte dos militares. Seus companheiros, amedrontados com as saraivadas de balas de metralhadoras sobre suas cabeças, acabaram cedendo, dando passagem à composição. Finalizada a confusão, quando os soldados também se retiraram, constatou-se que Herval estava caído ao solo, bastante ferido, sendo então providenciado socorro. ${ }^{32}$

Segundo o próprio Herval Arueira, em entrevista concedida recentemente, o piquete de 79 ferroviários, por ele liderado, enfrentou um caso raríssimo na Leopoldina, de um trem que foi conduzido por um maquinista "fura-greve”. Acreditando que a composição estivesse vazia, os grevistas foram surpreendidos pela presença de tropas comandadas pelo Coronel Neiva. Quando os soldados desembarcaram da composição, dispararam tiros de festim e foram recebidos com as palavras de ordem e a disposição de resistência dos militantes, havendo troca de acusações entre os líderes de cada grupo:

nós pensávamos que o trem, eles tinham furado porque o trem estava vazio, mas quando o trem parou ... só saiu soldado do exército. Aí o coronel veio logo gri- 
tando: “desocupa a linha seus representantes de Moscou”. Aí eu disse: "Prove! Eu tenho certeza que nós não estamos aqui representando nação nenhuma, nós estamos aqui representando os ferroviários brasileiros, da Leopoldina e dos demais ferroviários brasileiros. Agora, de uma coisa eu tenho certeza, isso eu garanto ao senhor, porque o senhor sabe o que eu vou falar, o senhor pode dizer que não, mas a sua mente não pode te trair. Agora nós temos certeza que os senhores são representantes dos States, do Pentágono, do Departamento de Estado.” ... tudo na presença dele, dos soldados, dos companheiros. ${ }^{33}$

Após as trocas de acusações vieram as agressões. Em estado grave, Herval Arueira percorreu três hospitais e ficou internado vários dias. Espancamentos como o dele não eram coisa incomum. Em outubro de 1955, por exemplo, o Sindicato dos Trabalhadores nas Empresas de Carris Urbanos protestou contra espancamento dos membros do sindicato concentrados em frente ao Palácio do Catete, em manifestação pacífica contra as demissões em massa. ${ }^{34}$

Tais militantes, apesar de tudo, sobreviveram. Não teve a mesma sorte o tecelão Altair de Paula Rosa, de 23 anos, que foi morto com um tiro na nuca numa ação policial contra grevistas, durante a greve da sua categoria, em dezembro de 1952. Apesar de a imprensa ter noticiado a morte do trabalhador como resultante do confronto com policiais, o inspetor que produziu um relatório sobre o tema para a DPS tratou do caso como resultado de uma "tentativa de sabotagem".35

\section{CONSIDERAÇÕES FINAIS}

Constata-se, portanto, a partir de uma visita, ainda que rápida, à documentação policial, que os governos do período dito democrático do pós-1945 mantiveram ativo e mesmo aperfeiçoaram o braço repressivo no seu ramo especializado na vigilância e repressão aos sindicatos, tendo as greves como um de seus principais alvos. Se esse é um fato, é possível entender que períodos de declínio das greves - como os anos de 1947 e 1948 - foram realmente marcados pela forte presença repressiva do Estado, mas torna-se mais importante ainda ressaltar que as greves voltaram a crescer em número nos anos seguintes, atingindo uma proporção inédita a partir da segunda metade da década de 1950 e que toda a vigilância/repressão aos movimentos naquele período não foi capaz de evitá-las ou controlá-las.

Observando tais greves, foi-nos possível avançar na crítica de interpretações ainda correntes que pensam a relação entre Estado e sindicatos no pe- 
ríodo exclusivamente a partir das imposições restritivas e controladoras da estrutura sindical oficial, não dando conta de explicar (e muitas vezes negando sua evidência) o grande número de paralisações, bem como a grande presença de organizações por local de trabalho na preparação, organização e/ou condução de muitas greves. Desprezam também a existência de muitas paralisações movidas contra a Justiça do Trabalho e suas decisões, que tomavam a legislação trabalhista, muitas vezes desrespeitada pelos patrões, não como uma dádiva, mas como direitos ainda a conquistar, o que desmente de forma análoga as hipóteses mais recentemente discutidas pelos historiadores do período de uma tradição trabalhista vista como "cornucópia" de direitos, que garantia o apoio dos trabalhadores aos governantes por conta da efetividade das políticas sociais. E conforme também apontamos, não se sustentariam quaisquer hipóteses de aceitação passiva das propostas políticas dos governantes pela classe trabalhadora se não fosse a pouca atenção até aqui conferida pela historiografia ao peso de outro braço da ação estatal frente às mobilizações sindicais - a polícia política — cuja existência e amplitude de atuação constituem por si um questionamento a tais interpretações.

Greves e repressão policial não eram, com certeza, as duas únicas modalidades de ação dos trabalhadores e de resposta do Estado. Porém, conhecêlas melhor é indispensável para a construção de interpretações mais amplas sobre o complexo quadro de conflito social aberto e disputa de projetos políticos que antecedeu o golpe militar de 1964.

\section{NOTAS}

${ }^{1}$ Professor da Universidade Federal Fluminense. A pesquisa aqui refletida contou com o apoio da Faperj e reuniu uma equipe de pesquisadores composta por Paulo Tenório de Abreu, Luciana Lombardo da Costa Pereira, Júlia Monnerat Barbosa, Francisco Josué Medeiros de Freitas e Nina Paiva Almeida. Seu resultado final está reunido em MATTOS, M. B. (Coord.) Greves e repressão policial ao sindicalismo carioca. Rio de Janeiro: Aperj/Faperj, 2003.

${ }^{2}$ RODRIGUES, L. M. Sindicalismo e classe operária (1930-1964). In: FAUSTO, B. (Org.) História Geral da Civilização Brasileira. Tomo III, v.III, 3.ed., São Paulo: Difel, 1986, p.542; SANDOVAL, S. Os trabalhadores param. Greves e mudança social no Brasil - 1945-1964. São Paulo: Ática, 1994.

${ }^{3}$ Um quadro com o conjunto dos dados sobre greves recuperados pela pesquisa pode ser acessado em www.historia.uff.br/greves. 
${ }^{4}$ TILLY, C., SHORTER, E. Strikes in France. 1830-1968. Cambridge: Cambridge University Press, 1974.

${ }^{5}$ Para dois exemplos deste tipo de uso da noção de sindicalismo populista, ver RODRIGUES, L. M. Industrialização e atitudes operárias. São Paulo: Brasiliense, 1970; WEFFORT, F. Origens do sindicalismo populista no Brasil - a conjuntura do após-guerra. Estudos Cebrap , n.4. São Paulo, abr./jun., 1973. Consideramos as caracterizações feitas pelos autores convergentes, mesmo trabalhando o primeiro com explicações para o comportamento sindical baseadas na origem de classe dos operários e o segundo centrando sua argumentação nas opções políticas das direções.

${ }^{6}$ Para a caracterização das greves segundo este padrão, o estudo clássico é o de RODRIGUES, L. M. Sindicalismo e conflito industrial no Brasil. São Paulo: Difel, 1966. Estudo mais recente que pretendeu reforçar o modelo de Rodrigues foi o de BOITO Jr., A. O sindicalismo de Estado no Brasil: uma análise crítica da estrutura sindical. São Paulo: Hucitec, Ed. Unicamp, 1991.

${ }^{7}$ Ver por exemplo SILVA, F. T. da. A carga e a culpa. Operários das docas de Santos: direitos e cultura de solidariedade. 1937-1968. São Paulo: Hucitec/Pref. Municipal de Santos, 1995; e COSTA, H. da. Em busca da memória. São Paulo: Scritta, 1997.

${ }^{8}$ Essa greve é comentada por MIGLIOLI, J. Como são feitas as greves no Brasil. Rio de Janeiro: Civilização Brasileira, 1963, p.58.

${ }^{9}$ Sobre essas greves, ver MATTOS, M. B. Novos e velhos sindicalismos no Rio de Janeiro. Rio de Janeiro: Vício de Leitura, 1998, e OLIVEIRA, A. L. S. C. Sindicato e sindicalismo bancário. Rio de Janeiro: Edur/SEEB-RJ, 1998.

${ }^{10}$ Ver a esse respeito as considerações de FRENCH, J. Afogados em leis. A CLT e a cultura política dos trabalhadores brasileiros. São Paulo: Fund. Perseu Abramo, 2001.

${ }^{11}$ Assim, por exemplo, Jorge Ferreira compara a legislação brasileira ao Welfare State europeu, ao propor a substituição por trabalhismo do conceito de populismo, segundo ele marcado pela preocupação em descaracterizar que "políticas públicas que garantam os direitos sociais dos trabalhadores, são modelos de economia e de sociedade que, na Europa Ocidental, ficaram conhecidos como Estado de Bem-Estar Social'. FERREIRA, J. O nome e a coisa: o populismo na política brasileira. In: O populismo e sua história. Debate e crítica. Rio de Janeiro: Civilização Brasileira, 2001, p.124. Na mesma linha, Daniel Aarão Reis argumenta, em artigo na mesma coletânea, que a "tradição trabalhista" sustentava-se numa "cornucópia" de direitos, com "Redes de proteção para os trabalhadores: institutos de aposentadoria e pensões, sindicatos assistencialistas, justiça do trabalho, em cuja administração as lideranças sindicais participavam ativamente: uma cornucópia." REIS FILHO, D. A. O colapso do colapso do populismo ou a propósito de uma herança maldita. In: FERREIRA, J. (Org.) O populismo e sua história..., op. cit., p.346-7. Uma discussão mais aprofundada dessas teses pode ser encontrada no primeiro capítulo de MATTOS, M. B. (Coord.) Greves e repressão..., op. cit. 
${ }^{12}$ SILVA, F. T. da. A carga e a culpa..., op. cit., p.162 ss.

${ }^{13}$ Estes movimentos foram tratados em MATTOS, M. B. Novos e velhos sindicalismos..., op. cit.

${ }^{14}$ Entrevista de Demisthóclides Batista a Pedro Tórtima e Bernardo Kocher, Rio de Janeiro, 14 de junho de 1989. LABHOI/UFF.

${ }^{15}$ Maiores informações sobre esse movimento podem ser encontradas no livro de memórias de Paulo de Mello Bastos. Salvo Conduto. Um vôo na história. Rio de Janeiro: Garamond, 1998.

${ }^{16} \mathrm{O}$ estudo mais detalhado de que dispomos, com estas preocupações (mas também incluindo a variável política em sua análise) é o de LOBO, E. et al. Rio de Janeiro operário. Natureza do Estado, conjuntura econômica, condições de vida e consciência de classe. Rio de Janeiro: Access, 1992.

${ }^{17}$ Para um detalhamento dos valores do salário mínimo, a melhor fonte é a série histórica traçada pelo DIEESE (www.dieese.org.br).

${ }^{18}$ Dados sobre as taxas de inflação do período podem ser encontrados em LOBO, E. et al. O Rio de Janeiro operário..., op. cit.

${ }^{19}$ Durante o governo Goulart, os índices de crescimento do PIB caíram de 7,7\% em 1961, para 2\% em 1963. LOBO, E. et al. O Rio de Janeiro..., op. cit., p.358.

${ }^{20}$ Entrevista publicada em FIGUEIREDO, B. G. (Org.) Batistinha: o combatente dos trilhos. Rio de Janeiro: CMF/AMORJ, 1994, p.39.

${ }^{21}$ Trabalhamos com as seguintes fontes para traçar este sintético histórico da polícia política: APERJ. Divisão de Polícia Politica e Social. DPS. 1944-1962. História Administrativa. Rio de Janeiro, 1998. APERJ. DOPS: a lógica da desconfiança. Rio de Janeiro, 1996. SAMIS, A. Clevelândia. Anarquismo, sindicalismo e repressão política no Brasil. São Paulo: Imaginário, 2002.

${ }^{22}$ Ver, a respeito da evolução histórica da legislação sobre greves, os textos de Silvia Saboya Lopes e Lizete Belido Barreto, na coletânea organizada por NASCIMENTO, A. M. R. e VIDAL NETO, P. Direito de greve: coletânea de direito do trabalho. São Paulo: LTR, 1984.

${ }^{23}$ Esses dados correspondem a uma amostra significativa, mas distante do total, da documentação arquivada no Aperj, pois referem-se apenas à Série de 21 maços agrupados com a designação "Sindicatos", no Fundo DOPS. Há, para o mesmo período, outras séries grandes de documentos, agrupadas no Fundo DPS. Ver PEREIRA, L. L. da C. Os papéis azuis da repressão. Niterói: UFF, 2000. (Monografia de final de curso de Graduação).

${ }^{24}$ Fundo DPS. Dossiê Movimento Sindical. 30074, fl. 729 ss. As duas citações de documentos a seguir foram extraídas do mesmo dossiê, fls. 695 e 699.

${ }^{25}$ Fundo DPS. Dossiê Movimentos Grevistas (30152). Ocorrências de 22/5/59. Fls. 199 (v). Aperj. 
${ }^{26}$ Prontuário de Gervásio Telles, Aperj.

${ }^{27}$ Fundo PPRJ, Dossiê Greves, Pasta 2, ref. “Protocolo N. 16955/1960”. Aperj.

${ }^{28}$ FIGUEIREDO, B. G., op. cit., p.25, 31, 34.

${ }^{29}$ In DPS. Movimento Sindical. Dossiê 30074, fl. 853. Aperj.

${ }^{30}$ DPS. Movimento Grevista do Distrito Federal (1954-1955), Dossiê 62, fl. 861 (Diário de Notícias, 21/9/1954), Aperj.

${ }^{31}$ Fundo DPS. Dossiê Movimento Sindical, 30074, fl. 738. Aperj.

${ }^{32}$ Ibidem, fl. 849.

${ }^{33}$ Entrevista de Herval Arueira a Paulo Tenório de Abreu, em 7/6/2000.

${ }^{34}$ Fundo DOPS. Série Sindicatos, dossiê 17, maço 1. Aperj.

35 "Relatório dos acontecimentos de 5 de dezembro". Polícia Política, Série Sindicatos, pasta 10, fls. 49-51. Aperj. 